\title{
ANALISIS KEMAMPUAN KOGNITIF DAN KESULITAN BELAJAR SISWA MATERI SISTEM EKSKRESI DI SMA NEGERI 1 KARANG BARU
}

\author{
Fitri Amini ${ }^{1^{*}}$, Mhd Yusuf Nasution ${ }^{2}$, Mulkan $^{3,}$ Hartati Sugito ${ }^{4}$ \\ 1,2 Program Studi Pendidikan Biologi, FMIPA, Universitas Negeri Medan, Jl. Willem Iskandar Psr.V, Medan \\ Estate, Medan, Indonesia, 20221 \\ ${ }^{3,4}$ SMA N 1 Karang Baru Kabupaten Aceh Tamiang, Jalan Desa Medang Ara Karang Baru , Aceh Tamiang, Aceh, \\ Kode Pos 24476 \\ *E-mail : fitriamini63@gmail.com
}

\begin{abstract}
ABSTRAK
Penelitian ini bertujuan untuk mengetahui kesulitan belajar siswa pada materi sistem ekskresi ditinjau dari aspek kognitif dan indikator pembelajaran serta faktor penyebab kesulitan belajar siswa di kelas XI IPA SMA Negeri 1 Karang Baru Tahun Pembelajaran 2017/2018. Desain penelitian yang digunakan yaitu deskriptif kuantitatif. Sampel diambil secara purposive sampling dengan jumlah 95 siswa. Teknik pengumpulan data dengan menggunakan tes diagnostic dan angket. Hasil penelitian menunjukkan persentase kesulitan belajar siswa yang tertinggi sampai terendah pada aspek kognitif yaitu C6,C4,C5,C3,C1 dan C2 sebesar 47,37\%, 46,5\%, $46,00 \%, 39,61 \%, 34,74 \%$ dan 26,53\%. Persentase kesulitan belajar siswa berdasarkan indikator pada materi sistem ekskresi yaitu indikator 1 sebesar 28,95\% kategori sedang, indikator 2 sebesar 46,02\% kategori sangat tinggi, indikator 3 sebesar 39,89\% kategori tinggi dan indikator 4 sebesar 42,32\% kategori tinggi. Faktor internal dan eksternal penyebab kesulitan belajar dari persentase kesulitan belajar tertinggi sampai terendah yaitu keluarga $(63,15 \%)$, minat $(63,02 \%)$, sekolah $(63,00 \%)$, psikologi $(46,57 \%)$, metode mengajar $(45,21 \%)$, materi $(44,42 \%)$, motivasi $(44,21 \%)$, media $(44,21 \%)$, guru $(44,12 \%)$, dan kesehatan $(44,03 \%)$.
\end{abstract}

Kata Kunci : Aspek Kognitif, Indikator Pembelajaran, Kesulitan Belajar, Sistem Ekskresi

\section{ABSTRACT}

This study aims to determine students' learning difficulties in the excretory system material in terms of cognitive aspects and learning indicators as well as the factors causing student learning difficulties in class XI IPA 1 Karang Baru at the year learning 2017/2018. The research design used is quantitative descriptive. Samples were taken by purposive sampling with a total of 95 students. The technique of data collection used diagnostic and questionnaire tests. The results showed that the percentage of students' learning difficulties from the highest to the lowest on the cognitive aspects they are C6, C4, C5, C3, C1 and C2 of $47.37 \%$,for amount $46.5 \%, 46.00 \%, 39.61 \%, 34.74 \%$ and $26.53 \%$. The percentage of student learning difficulties based on indicators on the excretion system material are indicator 1 amount 28.95\% medium category, indicator 2 amount $46.02 \%$ of very high category, indicator 3 amount $39.89 \%$ of high category and indicator 4 amount $42.32 \%$ of category high. Internal and external factors that cause the learning difficulties of learning difficulties from the highest to the lowest percentage are family $(63,15 \%)$, interest $(63,02 \%)$, school $(63,00 \%)$, psychology $(46,57 \%)$, teaching methods $(45,21 \%)$, material $(44,42 \%)$, motivation $(44,21 \%)$, media $(44,21 \%)$, teachers $(44,12 \%)$ and health $(44,03 \%)$.

Keywords: Cognitive Aspects, Excretion Systems, Learning Difficulties, Learning Indicators

\section{PENDAHULUAN}

Belajar merupakan perubahan tingkah laku atau penampilan, perubahan ini terdiri dari serangkaian kegiatan yaitu terdiri dari membaca, mengamati, mendengarkan, meniru dan lain sebagainya (Sardiaman, 2011). Perubahan yang terjadi dalam diri seseorang banyak sekali baik dari perubahan sifat maupun perubahan jenisnya, karena itu sudah tentu tidak setiap perubahan dalam diri seseorang merupakan perubahan dalam arti belajar (Slameto, 2010). Belajar itu merupakan kegiatan yang kompleks. Kompleksitas belajar itu dapat dipandang dari dua subjek, yaitu dari segi siswa dan segi guru (Mudjiono dan Dimyati, 2009). Ada banyak faktor-faktor yang mempengaruhi belajar siswa, yaitu terdiri dari faktor internal dan faktor eksternal. Faktor internal yaitu faktor yang 
ada dalam diri siswa tersebut ketika belajar terdiri dari faktor jasmani, psikologis dan kelelahan, sedangkan faktor eksternal yaitu faktor yang berasal dari luar diri siswa tersebut terdiri dari faktor keluarga, sekolah dan masyarakat (Syah, 2012).

Dalam kegiatan belajar mengajar siswa sering mengalami kesulitan belajar. Kesulitan belajar siswa dapat mengakibatkan hasil belajar siswa tersebut menjadi rendah. Kesulitan belajar dapat dibagi menjadi dua kelompok yaitu kesulitan belajar yang berhubungan dengan perkembangan dan kesulitan belajar yang berhubungan dengan akademik (Abdurrahman, 2018).

Kesulitan belajar siswa dapat dipengaruhi oleh berbagai faktor. Menurut penelitian siregar (2016), faktor yang mempengaruhi kesulitan belajar siswa yaitu faktor psikologi, keluarga dan faktor biologis. Sedangkan menurut penelitian Sianturi dan Tumiur (2016), Faktor yang mempengaruhi kesulitan belajar siswa yang dalam kategori menghambat yaitu indikator intelegensi, orang tua, indikator suasana rumah, guru, lingkungan sekolah dan indikator mata pelajaran. Faktor mata pelajaran ini termasuk faktor dengan persentase tertinggi dalam kesulitan belajar siswa. Ini dikarenakan faktor mata pelajaran biologi ini terlalu banyak menghapal dan mengandung banyak istilah latin sehingga membuat siswa bosan dan sulit memahami pelajaran biologi tersebut. Hasil belajar siswa sangat dipengaruhi oleh kesulitan belajar siswa tersebut, semakin tinggi tingkat kesulitan belajar siswa maka hasil belajar siswa akan rendah begitu sebaliknya.

Berdasarkan hasil wawancara dengan dengan salah satu guru biologi bidang studi mata pelajaran biologi SMAN 1 Karang Baru diketahui masih banyak siswa yang mengalami kesulitan belajar atau tidak mencapai ketuntasan belajar ditandai dengan adanya nilai siswa yang belum memenuhi target pencapaian dan banyaknya siswa yang mengeluh tentang mata pelajaran biologi. Hal ini diperoleh dengan berdasarkan data nilai siswa dimana 50\% dibawah nilai KKM, yaitu 75 .

Dari hasil wawancara juga diketahui banyak siswa yang berpendapat bahwa materi sistem ekskresi merupakan pelajaran yang kurang disukai bahkan membosankan karena pelajaran tersebut menghafal, sulitnya terminologi maupun bahasa latin pada pengenalan organ yang terlibat, sulit membedakan proses pengeluaran pada manusia, konsep yang diberikan rumit, terdapat unsur kimia pada praktikum yang dilakukan, dan sulit dimengerti karena penjelasannya terlalu panjang seperti proses pembentukan urin. Di samping itu juga masih kurangnya pemanfaatan fasilitas sekolah dalam pembelajaran biologi tentang sistem ekskresi serta kurangnya motivasi guru dalam setiap model pembelajaran yang dibuat.

Untuk memahami seberapa besar tingkat kesulitan siswa dalam belajar, maka dapat dilakukan dengan berbagai cara. Salah satunya dengan menganalisis hasil evaluasi belajar siswa. Setelah diketahui kesulitan yang dihadapi siswa dan seberapa besar tingkat kesulitan tersebut dapat diatasi. Dari hasil analisis kesulitan itu pula, dapat diketahui faktor penyebab kesulitan belajar. Berdasarkan uraian di atas maka dilakukan penelitian tentang Analisis Kemampuan Kognitif dan Kesulitan Belajar Siswa Materi Sistem Ekskresi Di SMA Negeri 1 Karang Baru Tahun Pembelajaran 2017/2018.

\section{METODE PENELITIAN}

Penelitian ini dilaksanakan di SMA Negeri 1 Karang Baru Kabupaten Aceh Tamiang pada bulan Mei sampai Juli Tahun 2018. Populasi penelitian ini adalah seluruh siswa kelas XI MIA Semester II SMA Negeri 1 Karang Baru Kabupaten Aceh Tamiang Tahun Pembelajaran 2017/2018 yang terdiri dari 121 siswa dalam 5 kelas dan sampel yang digunakan yaitu sebanyak 4 kelas XI MIA berjumlah 95 siswa, penentuan sampel dengan menggunakan teknik purposive sampling.

Jenis penelitian ini merupakan penelitian deskriptif kuantitatif. Instrument yang digunakan yaitu tes hasil belajar dan angket. Tes hasil belajar yang digunakan sebanyak 30 soal dan angket yang digunakan sebanyak 40 soal.

Tes hasil belajar disusun dalam bentuk pilihan ganda dengan 5 option $(a, b, c, d, e)$ berdasarkan taksonomi bloom yaitu Pengetahuan (C1), Pemahaman (C2), Aplikasi (C3), Analisis (C4), Sintesis (C5) dan Evaluasi (C6). Setiap soal yang dijawab benar mendapat skor 1 dan yang salah mendapat skor 0 . Untuk memperoleh data yang dibutuhkan, maka untuk tes hasil belajar yang digunakan harus dilakukan beberapa uji terlebih dahulu yaitu uji validitas, uji reliabilitas, taraf kesukaran soal, daya pembeda soal (Arikunto, 2013). 
Tabel 1. Kisi-Kisi Tes Hasil Belajar

\begin{tabular}{|c|c|c|c|c|c|c|c|c|}
\hline \multirow[t]{2}{*}{ No } & \multirow[t]{2}{*}{ Indikator } & \multicolumn{6}{|c|}{ Aspek Kognitif } & \multirow[t]{2}{*}{ Jumlah } \\
\hline & & $\mathrm{C} 1$ & $\mathrm{C} 2$ & C3 & $\mathrm{C4}$ & $\mathrm{C} 5$ & C6 & \\
\hline 1 & $\begin{array}{l}\text { Mengidentifikasikan zat-zat } \quad \text { dalam } \\
\text { metabolisme tubuh manusia }\end{array}$ & 1,3 & 10, & & 29 & & & 4 \\
\hline 2 & $\begin{array}{l}\text { Mengidentifikasikan organ-organ pada } \\
\text { sistem eksresi manusia }\end{array}$ & 23 & $\begin{array}{l}13, \\
19,\end{array}$ & $\begin{array}{l}18, \\
27\end{array}$ & 25 & 7, & & 7 \\
\hline 3 & $\begin{array}{l}\text { Mendeskripsikan sistem eksresi pada tubuh } \\
\text { manusia }\end{array}$ & & 4 & $\begin{array}{l}11, \\
12, \\
16, \\
22\end{array}$ & $\begin{array}{l}2, \\
28\end{array}$ & & $\begin{array}{l}17 \\
20\end{array}$ & 9 \\
\hline 4 & $\begin{array}{l}\text { Mengidentifikasi gangguan dan penyakit } \\
\text { pada sistem eksresi manusia }\end{array}$ & & 5 & $\begin{array}{l}6 \\
30\end{array}$ & $\begin{array}{l}8, \\
15\end{array}$ & $\begin{array}{c}9,14 \\
21,24 \\
26\end{array}$ & & 10 \\
\hline & Jumlah & 3 & 5 & 8 & 6 & 6 & 2 & 30 \\
\hline
\end{tabular}

Dari hasil belajar siswa ditentukan ketuntasan belajar siswa secara individual dengan rumus:

$$
\mathrm{KB}=\frac{T}{T_{t}} \times 100 \%
$$

Keterangan:

$$
\begin{array}{ll}
\mathrm{KB} & =\text { Ketuntasan Belajar } \\
\mathrm{T} & =\text { Jumlah skor yang diperoleh siswa } \\
\mathrm{Tt} & =\text { Jumlah skor Total }
\end{array}
$$

Tabel 2. Kisi - Kisi Angket Faktor-Faktor Kesulitan Belajar Siswa Tentang Sistem Ekskresi

\begin{tabular}{clcc}
\hline No & \multicolumn{1}{c}{ Aspek yang diamati } & No Item & Jumlah Item \\
\hline 1 & Kesehatan & $1,2,3$ & 3 \\
2 & Minat & $4,5,6,7$ & 4 \\
3 & Motivasi & $8,9,10,11$ & 4 \\
4 & Psikologi & $12,13,14$ & 3 \\
5 & Keluarga & $15,16,17$ & 3 \\
6 & Sekolah & $18,19,20,21,22$ & 5 \\
7 & Guru & $23,24,25$ & 3 \\
8 & Materi Pelajaran & $26,27,28,29,30,31$ & 6 \\
9 & Media & $32,33,34,35$ & 4 \\
10 & Metode/ Strateg Belajar & $36,37,38,39,40$ & 5 \\
\hline
\end{tabular}

Hasil angket dianalisis dengan cara menganalisis data angket dengan mencari persentase dari setiap indikator yang diteliti. Persentase jawaban angket siswa untuk masing masing aspek dari tiap indikator dengan rumus menurut Trianto, (2010) :

$$
\% \text { jawaban }=\frac{\text { Skor yang dicapai }}{\text { Skor ideal }} \times 100 \%
$$

Untuk tes hasil belajar, analisis data dimulai dengan mencari daya serap siswa untuk setiap item dalam tes dengan rumus (Trianto, 2010):

$$
\text { Daya Serap }=\frac{\text { Skor } \text { Total Tiap Item }}{N \text { X bobot }} \times 100 \%
$$

Setelah memperoleh daya serap siswa dalam bentuk persentase pada setiap aspek kognitif (C1-C6) maka diperoleh persentase kesulitan belajar dengan cara mengurangkan sertus persen daya serap dengan daya serap hasil perhitungan. 
Tabel 3. Distribusi Kesulitan Belajar Siswa Berdasarkan Aspek Kognitif

\begin{tabular}{ccccc}
\hline No & Aspek Kognitif & $\begin{array}{c}\text { Daya Serap Siswa } \\
(\%)\end{array}$ & $\begin{array}{c}\text { Kesulitan Belajar } \\
\text { Siswa (\%) }\end{array}$ & Kategori Kesulitan \\
\hline 1. & C1 & $65,26 \%$ & $34,74 \%$ & Sedang \\
2. & C2 & $73,47 \%$ & $26,53 \%$ & Sedang \\
3. & C3 & $60,39 \%$ & $39,61 \%$ & Tinggi \\
4. & C4 & $53,50 \%$ & $46,50 \%$ & Sangat Tinggi \\
5. & C5 & $54,00 \%$ & $46,00 \%$ & Sangat tinggi \\
6. & C6 & $52,63 \%$ & $47,37 \%$ & Sangat tinggi \\
\hline
\end{tabular}

Pada aspek kognitif, persentase kesulitan belajar siswa pada tingkat pengetahuan (C1) yaitu sebesar $34,74 \%$ termasuk kategori tingkat kesulitan sedang, pada tingkat pemahaman (C2) yaitu sebesar $26,53 \%$ termasuk kategori tingkat kesulitan sedang, pada tingkat penerapan (C3) sebesar 39,61\% termasuk kategori tingkat kesulitan tinggi, pada tingkat analisis (C4) sebesar 46,5\% termasuk kategori tingkat kesulitan sangat tinggi, pada tingkat sintesis (C5) sebesar $46 \%$ termasuk kategori tingkat kesulitan sangat tinggi dan pada tingkat kreasi (C6) sebesar 47,37\% termasuk kategori tingkat kesulitan sangat tinggi.

\section{Kesulitan Belajar Siswa Berdasarkan Aspek Kognitif}

a. Aspek Pengetahuan (C1)

Dari hasil jawaban siswa pada aspek pengetahuan dapat diketahui bahwa siswa memiliki kemampuan dasar yang cukup tentang zat-zat sisa yang dihasilkan dari organ-organ ekskresi.

b. Aspek Pemahaman (C2)

Hasil jawaban siswa masih kurang pada saat menentukan bagian-bagian pada kulit yang mengeluarkan zat sisa dan siswa masih kurang memahami penyakit-penyakit yang terjadi pada ginjal dan penyebab penyakit tersebut.

c. Aspek Penerapan (C3)

Kesulitan dalam menjawab soal pada aspek ini disebabkan siswa tidak benar-benar menerapkan pengetahuannya pada materi sistem ekskresi secara mendalam. Siswa kurang memahami proses ekskresi pada kehidupan sehari- hari dan sulit memahami proses yang terjadi pada bagian-bagian nefron.

d. Aspek Analisis (C4)

Berdasarkan jawaban siswa pada soal diketahui bahwa sebagian besar siswa belum dapat menganalis dengan baik hal-hal yang berhubungan dengan sistem ekskresi, kelainan dan zat sisa metabolisme yang diekskresikan oleh organ hati.

e. Aspek Sintesis (C5)

Pada aspek sintesis ini siswa masih banyak yang menjawab salah terutama pada pertanyaan jenis-jenis gangguan atau penyakit pada sistem ekskresi dan penyebab dari penyakit-penyakit tersebut pada tubuh manusia.

f. Aspek kreasi (C6)

Pada aspek ini siswa belum memahami dengan baik bagaimana tata urutan seharusnya pada proses pembentukan urine dan bagaimana faktor - faktor yang mempengaruhi produksi urin tersebut.

Untuk tingkat kesulitan yang sedang terdapat pada indikator ke-1 yaitu mengidentifikasikan zat-zat dalam metabolisme tubuh manusia dengan persentase kesulitan 28,95\%, lalu untuk kategori kesulitan tinggi terdapat pada indikator ke-3 yaitu mendeskripsikan sistem ekskresi pada tubuh manusia dengan persentase kesulitan 39,89\% dan indikator ke-4 yaitu mengidentifikasi gangguan dan penyakit pada sistem ekskresi manusia dengan persentase kesulitan 42,32\% dan untuk kategori kesulitan yang sangat tinggi terdapat pada indikator ke-2 yaitu mengidentifikasikan organorgan pada sistem ekskresi manusia dengan persentase kesulitan 46,02\%. 
Tabel 4. Distribusi Kesulitan Belajar Siswa Berdasarkan Indikator Pembelajaran

\begin{tabular}{llccc}
\hline No & Indikator Pembelajaran & $\begin{array}{c}\text { Daya Serap } \\
\text { Siswa (\%) }\end{array}$ & $\begin{array}{c}\text { Kesulitan Belajar } \\
\text { Siswa (\%) }\end{array}$ & $\begin{array}{c}\text { Kategori } \\
\text { Kesulitan }\end{array}$ \\
\hline 1. & $\begin{array}{l}\text { Mengidentifikasikan zat - zat dalam } \\
\text { metabolisme tubuh manusia }\end{array}$ & $71,05 \%$ & $28,95 \%$ & Sedang \\
2. & $\begin{array}{l}\text { Mengidentifikasikan organ - organ pada } \\
\text { sistem ekskresi manusia }\end{array}$ & $53,98 \%$ & $46,02 \%$ & Sangat Tinggi \\
3. & $\begin{array}{l}\text { Mendeskripsikan sistem ekskresi pada } \\
\text { tubuh manusia }\end{array}$ & $60,11 \%$ & $39,89 \%$ & Tinggi \\
4. & $\begin{array}{l}\text { Mengidentifikasi gangguan dan } \\
\text { penyakit pada sistem ekskresi manusia }\end{array}$ & $57,68 \%$ & $42,32 \%$ & Tinggi \\
\hline
\end{tabular}

\section{Kesulitan Belajar Siswa Berdasarkan Aspek Indikator Pembelajaran}

a. Mengidentifikasikan zat - zat dalam metabolisme

Pada indikator ini siswa sudah memahami pemahaman dasar tentang zat-zat apa saja yang dihasilkan metabolisme tubuh manusia, namun siswa masih belum dapat membedakan zat-zat yang dikeluarkan dari organ - organ ekskresi pada tubuh manusia.

b. Mengidentifikasikan organ - organ sistem eksresi

Pada indikator ini siswa mengalami kesulitan belajar yang paling tinggi. Siswa masih sulit membedakan bagian-bagian organ pada Faktor internal cukup mempengaruhi kesulitan belajar siswa. Kategori Cukup menghambat terdapat pada indikator kesehatan, motivasi dan psikologi yaitu sebesar 44,03\%, $44,21 \%$ dan $46,57 \%$. Sedangkan untuk kategori menghambat terdapat pada indikator minat yaitu sebesar $63,02 \%$. Selain faktor internal, faktor eksternal juga banyak mempengaruhi kesulitan belajar siswa. Untuk kategori cukup menghambat terdapat pada indikator guru sebesar 44,12\%, indikator materi sebesar $44,42 \%$, indikator media pembelajaran sebesar $44,21 \%$ dan indikator metode pembelajaran sebesar $45,21 \%$. Sedangkan untuk kategori menghambat terdapat pada sistem ekskresi dan sulit membedakan peranan setiap organ pada sistem ekskresi.

c. Mendeskripsikan proses sistem eksresi

Pada indikator ini siswa belum dapat memahami sistem ekskresi, bagaimana proses pengeluaran dan proses pembentukan urin dengan baik.

d. Mengidentifikasi gangguan dan penyakit sistem eksresi

Pada indikator ini terlihat bahwa siswa masih sulit membedakan penyakit dari organorgan sistem ekskresi dan sulit memahami penyebab penyakit pada organ-organ ekskresi.

\section{Hasil Angket}

indikator keluarga sebesar $63,15 \%$ dan indikator sekolah sebesar 63,00\%.

Berdasarkan hasil penelitian dapat diketahui bahwa faktor yang menghambat siswa dalam mempelajari sistem eksresi dari faktor internal yaitu faktor minat, sedangkan dari faktor eksternal yaitu faktor lingkungan keluarga dan sekolah. Untuk faktor yang cukup menghambat siswa dalam mempelajari sistem ekskresi dari faktor internal yaitu faktor kesehatan, motivasi dan psikologi sedangkan dari faktor eksternal yaitu faktor guru, media pembelajaran, materi pelajaran dan metode pembelajaran. 
Tabel 5. Kategori Faktor Penyebab Kesulitan Belajar

\begin{tabular}{lcc}
\hline Faktor Penyebab Kesulitan Belajar & Tingkat Kesulitan (\%) & Kategori \\
\hline A.Faktor Internal & & Cukup Menghambat \\
\hline Kesehatan & $44,03 \%$ & Menghambat \\
Minat & $63,02 \%$ & Cukup Menghambat \\
Motivasi & $44,21 \%$ & Cukup Menghambat \\
Psikologi & $46,57 \%$ & \\
& & \\
\hline B.Faktor Eksternal & & Menghambat \\
& & Cukup Menghambat \\
Keluarga & $63,15 \%$ & Cukup Menghambat \\
Sekolah & $63,00 \%$ & Cukup Menghambat \\
Guru & $44,12 \%$ & Cukup Menghambat \\
Materi & $44,42 \%$ & \\
Media & $44,21 \%$ & \\
Metode & $45,21 \%$ &
\end{tabular}

\section{Faktor Kesehatan}

Faktor kesehatan dilihat dari hasil jawaban angket siswa yang menyatakan bahwa mereka dapat melihat dan mendengar dengan jelas ketika guru biologi menjelaskan tentang materi sistem ekskresi walaupun sedikit dari siswa juga menyatakan bahwa mereka masih kurang jelas melihat tulisan guru di papan tulis. Selain itu siswa juga sering mengantuk ketika belajar sistem ekskresi. Menurut Ahmadi dan Supriyono (2004), untuk siswa yang yang kurang dapat melihat dan mendengar dengan jelas, apabila tidak mendapatkan perhatian guru, pasti akan mengalami kesulitan belajar. Sebab mereka tidak dapat memproses rangsangan dari guru atau teman-temannya karena alat indera mereka kurang berfungsi.

\section{Faktor Minat}

Faktor minat dilihat dari hasil jawaban angket siswa yang menyatakan bahwa mereka masih sulit untuk memahami materi sistem ekskresi yang diterangkan oleh guru biologi, rasa suka mereka untuk mempelajari sistem ekskresi juga sedikit terlihat dari banyaknya siswa yang menjawab mereka tidak suka belajar sistem ekskresi. Selain itu siswa hanya kadang-kadang mau mempersiapkan diri di rumah untuk mempelajari sistem ekskresi dan jarang mengulang pelajaran tentang sistem ekskresi di rumah. Menurut Ahmadi dan Supriyono (2004), menyatakan bahwa tidak adanya minat seseorang anak terhadap suatu pelajaran akan timbul kesulitan belajar. Karena jika si anak tidak memiliki minat belajar, maka pelajaran tersebut tidak akan pernah di proses di dalam otaknya.

\section{Faktor Motivasi}

Faktor motivasi dilihat dari jawaban hasil angket siswa menyatakan bahwa mereka sudah memahami pentingnya belajar sistem ekskresi yang terlihat dari jawaban mereka kalau materi sistem eksresi berguna untuk dipelajari. Namun banyak siswa yang berpendapat kalau materi sistem eksresi kurang mendukung pencapaian citacita mereka. Siswa juga kurang termotivasi untuk mencari sendiri jawaban permasalahan dari materi sistem ekskresi dan kurang tertarik untuk mempelajari lebih dalam tentang materi sistem ekskresi. Menurut Ahmadi dan Supriyono (2004), motivasi dapat menentukan baik tidaknya dalam mencapai tujuan sehingga semakin besar motivasinya akan semakin besar pula kesuksesan belajarnya.

\section{Psikologi}

Faktor psikologi dilihat dari jawaban hasil angket siswa siswa memiliki psikiatik yang kurang baik dalam mempelajari sistem ekskresi, hal itu terlihat dari sikap-sikap siswa yang tidak baik pada saat pembelajaran berlangsung. Sebagian siswa kurang berkonsentrasi pada saat guru menjelaskan materi, artinya mereka tidak dapat memusatkan perhatian mereka terhadap penjelasan guru. Menurut Ahmadi (2009), guru harus menjadi seorang psikolog dengan demikian guru akan mengetahui bagaimana cara anak belajar, berpikir, mengingat, memperhatikan dan sebagainya dengan baik, sehingga hasil belajar pun akan lebih baik.

\section{Faktor Keluarga}

Faktor keluarga ini merupakan faktor yang paling besar penyebab kesulitan belajar siswa. Diketahui dari hasil angket jawaban siswa bahwa orang tua mereka kurang mendukung dalam 
proses pembelajaran di rumah, selain itu orang tua tidak menyediakan bimbingan belajar di rumah dan anggota keluarga siswa seperti kakak atau abang mereka juga kurang membantu dalam proses belajar di rumah. Menurut Abdurrahman (2018), orang tua mempunyai lebih banyak waktu untuk bergaul dengan anak sehingga mereka dapat lebih leluasa untuk melakukan observasi perilaku anak dibandingkan dengan guru. Oleh karena itu, melatih mengembangkan keterampilan melakukan observasi perilaku anak merupakan kegiatan yang sangat bermanfaat dalam upaya mengatasi kesulitan belajar pada anak.

\section{Faktor Sekolah}

Faktor sekolah dilihat dari hasil jawaban angket siswa bahwa waktu yang digunakan untuk mempelajari materi sistem ekskresi masih kurang sehingga mereka tidak bisa memahami materi dengan baik. Kondisi ruangan kelas yang panas pun membuat siswa tidak nyaman dalam proses pembelajaran di kelas. Untuk fasilitas sekolah sudah memiliki fasilitas yang mendukung dalam proses pembelajaran. Mereka sudah pernah melaksanakan praktikum walaupun hanya sekali dalam proses belajar sistem ekskresi. Siswa juga masih jarang memanfaatkan perpustakaan untuk menambah wawasan mereka tentang sistem ekskresi. Menurut Ahmadi dan Supriyono (2004), kondisi gedung sekolah yang tidak memadai dan alat peraga yang kurang memadai akan memungkinkan pelajaran terhambat sehingga siswa akan mengalami kesulitan belajar.

\section{Faktor Guru}

Faktor guru dilihat dari hasil jawaban angket siswa diketahui bahwa guru dalam proses pembelajaran cukup demokratis, guru mau mendengarkan pendapat siswa ketika mengajar di kelas. Hanya saja guru masih berpenampilan kurang menarik sehingga siswa kurang tertarik dalam mendengarkan penjelasan guru. Namun guru di sekolah ini termasuk guru yang masuk tepat waktu ketika mengajar. Menurut Syah (2012), para guru yang selalu menunjukkan sikap dan perilaku yang simpatik dan memperlihatkan suri teladan yang baik dan rajin dapat menjadi daya dorong yang positif bagi kegiatan belajar siswa.

\section{Materi pelajaran}

Faktor materi pelajaran dilihat dari hasil jawaban angket siswa bahwa siswa masih kurang mengerti istilah-istilah yang digunakan pada materi sistem ekskresi, siswa juga kesulitan dalam mengingat nama latin, menyebutkan zat sisa yang dihasilkan berbagai organ yang terdapat pada sistem ekskresi, menjelaskan proses sistem ekskresi dan menyebutkan gangguan dan penyakit pada sistem eksresi. Namun siswa sudah banyak yang memahami apa saja organ-organ yang terdapat pada sistem ekskresi.

Menurut Rahmayani,dkk (2017), materi pelajaran sistem eksresi tergolong sulit terlihat dari tingkat kesulitan belajar siswa sebesar $68,35 \%$. Hal ini terjadi karena siswa kesulitan dalam memahami istilah-istilah dalam materi sistem ekskresi manusia, kesulitan dalam membedakan proses pengeluaran pada manusia pada materi sistem ekskresi manusia, dan siswa kesulitan dalam dalam menggambarkan organ, struktur dan fungsi pada sistem ekskresi manusia serta memahami gangguan dan penyakit pada sistem ekskresi manusia, sehingga siswa sulit pencapaiannya.

\section{Media Pembelajaran}

Faktor media dilihat dari hasil jawaban angket siswa bahwa siswa memiliki banyak kegiatan di luar sekolah, siswa juga banyak menghabiskan banyak waktu untuk menoton televisi dan bermain HP atau game online. Ini menyebabkan waktu mereka untuk belajar juga berkurang. Selain itu siswa juga jarang membaca buku atau sumber lainyang terkait dengan materi sistem ekskresi. Menurut Ahmadi dan Supriyono (2004), faktor media massa seperti TV, surat kabar, komik, handphone dan majalah disekeliling siswa akan menghambat belajar karena anak terlalu banyak waktu yang dipergunakan untuk itu, hingga lupa akan tugas belajarnya.

\section{Metode/strategi belajar}

Faktor metode/strategi belajar dilihat dari hasil jawaban angket siswa bahwa guru biologi sering menggunakan metode ceramah sehingga siswa mudah mengantuk ketika belajar. Guru juga kurang melakukan variasi dalam mengajar, sehingga siswa menjadi bosan dan kurang tertarik dalam belajar. Metode dan strategi pembelajaran yang diberikan guru juga sulit dipahami oleh siswa. Siswa juga sulit untuk menarik kesimpulan di akhir pembelajaran karena siswa tidak fokus ketika belajar sehingga mereka tidak mengetahui apa saja kesimpulan dari pembelajaran yang dijelaskan guru mereka. Menurut Ahmadi dan Supriyono (2004), metode mengajar yang tidak menarik, tidak menguasai bahan dan guru hanya menggunakan satu metode saja dan tidak bervariasi akan dapat menimbulkan kesulitan belajar siswa.

\section{KESIMPULAN}

Siswa kelas XI MIA SMAN 1 Karang Baru mengalami kesulitan dalam belajar materi Sistem Ekskresi pada aspek kognitif yaitu tingkat 
pengetahuan (C1) sebesar $34,74 \%$ dan tingkat pemahaman (C2) sebesar 26,53\% kategori sedang, tingkat penerapan (C3) sebesar 39,61\% kategori tinggi, tingkat analisis (C4) sebesar $46,5 \%$, tingkat sintesis (C5) sebesar 46,00\% dan tingkat kreasi (C6) sebesar 47,37\% kategori sangat tinggi. Kesulitan dalam belajar materi Sistem Ekskresi pada aspek indikator pembelajaran yaitu mengidentifikasikan zat-zat dalam metabolisme tubuh manusia sebesar 28,95\% kategori sedang,mendeskripsikan sistem ekskresi pada tubuh manusia sebesar $39,89 \%$ dan mengidentifikasi gangguan/penyakit pada sistem ekskresi manusia sebesar 42,32\% kategori tinggi, mengidentifikasikan organ-organ pada sistem ekskresi manusia sebesar 46,02\% kategori sangat tinggi.

Faktor penyebab kesulitan belajar siswa kelas XI MIA SMAN 1 Karang Baru pada materi Sistem Ekskresi untuk kategori menghambat adalah faktor minat, keluarga dan sekolah, dan untuk kategori cukup menghambat adalah faktor kesehatan, motivasi,psikologi, guru, materi, media dan metode. Penulis menyarankan bagi guru, untuk meningkatkan kualitas mengajar di kelas dengan melakukan variasi metode mengajar dan variasi model pembelajaran dalam mengajar dan bagi siswa, untuk lebih banyak membaca sumber referensi lain sehingga lebih menambah wawasan dan lebih meningkatkan semangat dan motivasi belajar.

\section{UCAPAN TERIMA KASIH}

Penulis mengucapkan terima kasih kepada staf dan para dosen FMIPA Pendidikan Biologi serta Guru SMA Negeri 1 Karang Baru Kabupaten Aceh Tamiang yang telah banyak membantu dan memberikan arahan dalam penyelesaian penelitian saya ini.

\section{DAFTAR PUSTAKA}

Abdurrahman, M., (2018), Pendidikan Bagi Anak Berkesulitan Belajar, PT.Rineka Cipta, Jakarta.

Ahmadi, A., (2009), Psikologi Umum, Rineka Cipta, Jakarta.

Ahmadi, A dan Supriyono, W., (2004), Psikologi Belajar, PT. Rineka Cipta, Jakarta.

Arikunto, S., (2013), Dasar - Dasar Evaluasi Pendidikan, Penerbit Bina Aksara, Jakarta.

Mudjiono dan Dimyati., (2009), Belajar dan Pembelajaran, Rineka Cipta, Jakarta.

Rahmayani., Sinambela, M dan Rosida., (2017), Analisis Faktor Kesulitan Belajar Siswa Pada Materi Pokok Sistem Ekskresi Manusia Kelas XI MIA SMA Negeri 16 Medan, Jurnal Pelita Pendidikan, 5(2): 055-065.

Sardiaman, (2011), Interaksi dan Motivasi Belajar Mengajar, Raja Grafindo Persada, Jakarta.

Sianturi, S dan Tumiur, G., (2016), Analisis Kesulitan Belajar Dan Hubungannya Dengan Hasil Belajar Siswa Pada Mata Pelajaran Biologi Siswa Kelas X Di SMA Negeri 1 Sidikalang Tahun Pembelajaran 2015/2016, Jurnal Pelita Pendidikan, 4(1): 170-178.

Siregar, N., (2012), Analisis Kesulitan Belajar Siswa Pada Mata Pelajaran Biologi di Kelas X Semester 1 SMA Negeri 1 Dolok Masihul Tahun Ajaran 2011/2012,http://digileb.unimed.ac.id.pu blic/UNIMED-Undergraduate-22715, (diakses pada 12 Maret 2018).

Slameto, (2010), Belajar dan Faktor - Faktor yang Mempengaruhi, Rineka Cipta, Jakarta.

Syah, M., (2012), Psikologi Belajar, Penerbit Rajawali Pers, Bandung.

Trianto, (2010), Mendesain Model Pembelajaran Inovatif-Progresif, Prenada Media, Jakarta. 